\title{
Factors Influencing Anxiety of Health Workers During Pandemic Covid-19
}

\author{
Lutfiana Inda Hapsari'1, Sri Mumpuni Yuniarsih'1, Rusdi Rusdi ${ }^{1}$
}

1 Program Studi Keperawatan Fakultas Ilmu Kesehatan, Universitas Pekalongan

\begin{tabular}{l}
\multicolumn{1}{c}{ Article Info } \\
\hline Article History: \\
Submitted: May $21^{\text {st }}, 2021$ \\
Accepted: June $29^{\text {th }}, 2021$ \\
Published: August $31^{\text {st }}, 2021$ \\
Keywords: \\
Healthcare workers; \\
Anxiety; Covid19 \\
\end{tabular}

\begin{abstract}
The Corona Virus has become a world health problem in early 2020. Coronavirus Disease 2019 (COVID-19) is a disease that has never been previously identified in humans. Health workers who are at the forefront of handling Covid-19 have high psychological disorders, one of which is anxiety. The purpose is to identify the factors that influence anxiety in health workers during the Covid-19 pandemic. The databases used include Google Scholar, PubMed Central and ResearchGate. 528 articles were found based on selected keywords, the number of articles after duplication-checking was 164 articles. Then screening was carried out according to the inclusion criteria $(n=20)$ and a total of 144 articles were eliminated because they did not match the inclusion criteria. The number of articles following the due diligence test $(n=10)$ and 10 articles were eliminated because they did not meet the due diligence requirements. Then 10 articles were taken for review. The results showed that the factors that influence anxiety in health workers are gender, age, family status, availability of PPE, knowledge, contact with COVID-19 patients, chronic disease, a physical and psychological workload that threatens the health, cooperation between colleagues, working in an infectious isolation ward. Psychological disorders such as anxiety have longterm impacts and can affect the work efficiency of health workers. If this anxiety is not managed properly, it can affect the performance of health workers in dealing with Covid-19. The most dominant factors affecting anxiety are age, the availability of PPE and concerns about transmission
\end{abstract}

\section{PENDAHULUAN}

Virus Corona (Covid19) merupakan masalah kesehatan dunia. Virus Corona mulai menyebar secara global di awal tahun 2020. Menurut data WHO per tanggal 19 Januari 2021 menunjukkan sebanyak 223 Negara terpapar virus corona dengan jumlah kasus corona virus yang terkonfirmasi sebanyak 93,956,883 jiwa [1]. Pandemi covid-19 berdampak pada gangguan kesehatan fisik, kesenjangan ekonomi, kesenjangan sosial dan gangguan mental salah satunya yaitu kecemasan. hal tersebut tidak hanya dirasakan oleh masyarakat tetapi juga profesi kesehatan [2].

Berdasarkan hasil penelitian yang dilakukan pada tenaga kesehatan di Arab Saudi, tenaga kesehatan sebagai garda terdepan sangat tertekan dengan bertambahnya kasus covid-19. Hal tersebut dibuktikan dengan empat ribu sembilan

Corresponding author:

Sri Mumpuni Yunarsih

unipekalongan@gmail.com

Media Keperawatan Indonesia, Vol 4 No 3, August 2021

e-ISSN: 2615-1669

ISSN: 2722-2802

DOI: $\underline{10.26714 / \mathrm{mki} \cdot 4.3 .2021 .218-225}$ 
ratus dua puluh petugas kesehatan dengan tingkat kecemasan yang dilaporkan adalah kecemasan rendah, sebanyak 1.552 orang $(31,5 \%)$ kecemasan sedang sebanyak 1.778 orang $(36,1 \%)$ dan kecemasan tinggi sebanyak 1.590 orang (32,3\%) [3]. Sedangkan menurut penelitian yang di lakukan di Rumah sakit Ethiopia sebanyak 63\% dari 503 tenaga kesehatan mengalami kecemasan. Hal tersebut dipengaruhi oleh status pernikahan, mengidap penyakit kronis, ketersediaan alat pelindung diri serta faktor usia [4].

Kecemasan merupakan suatu ketidaknyamanan yang diiringi dengan perasaan tidak berdaya dan perasaan tidak menentu. Tingginya tingkat kecemasan dapat berpengaruh terhadap daya tahan tubuh sesorang khususnya tenaga kesehatan sebagai garda terdepan sehingga beresiko terjadinya penularan covid-19 [2]. Dampak jangka panjang dari kecemasan yaitu menurunnya efisiensi kerja pada tenaga kesehatan [5]. Apabila kecemasan tidak dikelola dengan baik hal tersebut dapat berpengaruh terhadap kinerja tenaga kesehatan yang menangani covid-19. Untuk itu perlunya pengelolaan kecemasan yang baik dengan mengidentifikasi faktor-faktor yang dapat berpengaruh terhadap kecemasan. Berdasarkan uraian latar belakang diatas, perlu dilakukan identifikasi faktor-faktor yang mempengaruhi kecemasan pada tenaga kesehatan di masa pandemi Covid-19 sehingga dapat digunakan untuk pencegahan, pengobatan dan rehabilitasi tenaga kesehatan yang mengalami kecemasan.

\section{METODE}

Berdasarkan hasil identifikasi metode pencarian pada database Google Scholar, PubMed Central dan ResearchGate ditemukan sebanyak 528 data hasil pencarian. Proses pencarian database Google Scholar dengan kata kunci tenaga kesehatan, kecemasan, covid-19, cross sectional didapatkan sebanyak 164 artikel.
Hasil pencarian pada situs database PubMed Central menggunakan kata kunci health workers, anxiety, covid-19, cross sectional didapatkan 264 artikel. Sedangkan ada pencarian database ResearchGate dengan kata kunci healthcare workers, factor anxiety, covid19, cross sectional didapatkan 100 artikel. Alur proses pemilihan artikel penelitian dari 528 artikel yang ditemukan berdasarkan kata kunci yang dipilih, jumlah artikel setelah ceking duplikasi sebanyak 164 artikel. Kemudian dilakukan skrining sesuai dengan kriteria inklusi $(n=20)$ dan sebanyak 144 artikel dieliminasi karena tidak sesuai dengan kriteria inklusi. Jumlah artikel yang sesuai dengan uji kelayakan $(\mathrm{n}=10)$ dan sebanyak 10 artikel dieliminasi karena tidak memenuhi persyaratan uji kelayakan. Kemudian 10 artikel diambil untuk dilakukan review. Analisis penilaian kelayakan jurnal pada literature review ini yaitu dengan checklist daftar penilaian dengan pertanyaan untuk menilai kulitas dari penelitian. Kriteria penilaian diberi nilai 'ya, 'tidak', 'tidak jelas', 'tidak ada'. Setiap kriteria dengan skor 'ya' diberi poin satu dan nilai lainnya nol, kemudian hitung dan jumlahkan setiap penelitian. Apabila skor penelitian lebih dari 50\% maka dimasukkan kedalam kriteria inklusi. Apabila skor penelitian kurang dari 50\% maka jurnal penelitian tersebut akan dieksklusi. 


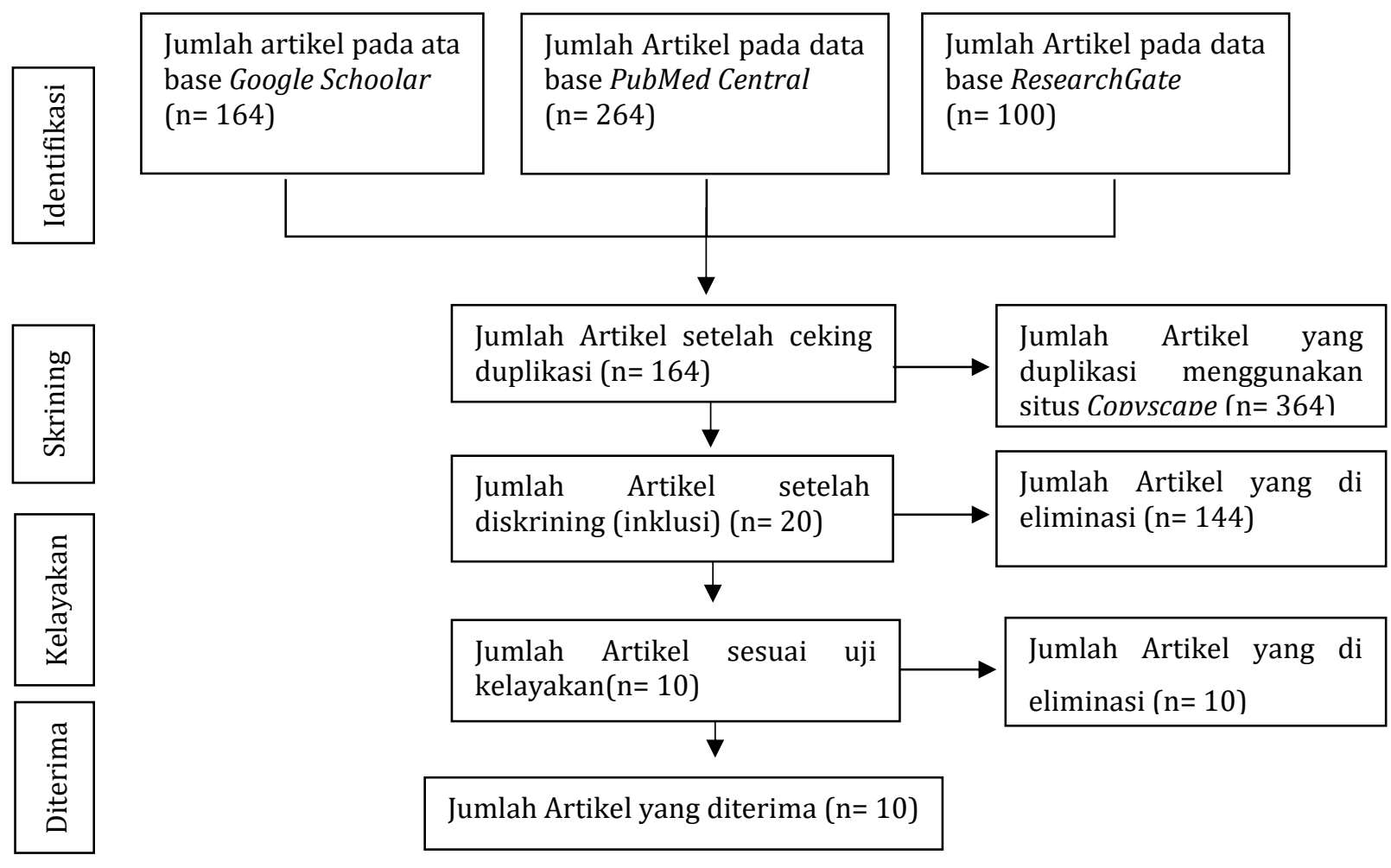

Gambar 1

Proses Pencarian Artikel

\section{HASIL}

Hasil dari proses identifikasi metode pencarian database Google Scholar, PubMed Central dan ResearchGate didapatkan sebanyak 528 data hasil pencarian. jumlah artikel setelah ceking duplikasi sebanyak 164 artikel. Kemudian dilakukan skrining sesuai dengan kriteria inklusi $(n=20)$ dan sebanyak 144 artikel dieliminasi karena tidak sesuai dengan kriteria inklusi. Jumlah artikel yang sesuai dengan uji kelayakan $(n=10)$ dan sebanyak 10 artikel dieliminasi karena tidak memenuhi persyaratan uji kelayakan. Kemudian terdapat 10 artikel yang akan direview.

Responden dalam penelitian adalah seluruh tenaga kesehatan yang terdampak Covid-19 di masing-masing negara. Dalam studi telah disebutkan Jumlah responden 10.140 responden. Responden laki-laki sebanyak 3.948 orang $(35,94 \%)$ sedangkan jumlah responden perempuan sebanyak 6.550 orang (56,63\%) namun 1 artikel tidak mencantumkan karakterisitik responden berdasarkan jenis kelamin. Hasil review dari 10 artikel tersebut menunjukan bahwa faktor-faktor yang mempengaruhi kecemasan pada tenaga kesehatan yaitu jenis kelamin, usia, status keluarga, ketersediaan APD, dan pengetahuan terhadap kecemasan tenaga kesehatan, tenaga medis yang pernah melakukan kontak langsung merawat pasien yang terinfeksi, mengidap penyakit kronis, beban kerja fisik dan psikis yang mengancam kesehatan, kekhawatiran tentang paparan SARS-CoV-2, kontak dengan pasien covid19, bekerja di bangsal isolasi infeksius. 
Tabel 1

Matrik sintesis

\begin{tabular}{|c|c|}
\hline & \\
\hline Sumber/Judul/Penulis/Tahun & Hasil \\
\hline $\begin{array}{l}\text { yang Mempengaruhi Kecemasan pada Tenaga } \\
\text { atan Dalam Upaya Pencegahan Covid-19 } \\
\text { s: Fadli, et.al (2020) }\end{array}$ & $\begin{array}{l}\text { Faktor-faktor yang mempengaruhi kecemasan tenaga } \\
\text { kesehatan dalam upaya pencegahan covid19 yaitu usia, } \\
\text { status keluarga, ketersediaan APD dan pengetahuan. }\end{array}$ \\
\hline $\begin{array}{l}\text { The prevalence and influencing factors in anxiety in } \\
\text { medical workers fighting COVID-19 in China: a cross- } \\
\text { sectional survey } \\
\text { Penulis : Chen-Yun Liu, et.al (2020) }\end{array}$ & $\begin{array}{l}\text { Menurut hasil penelitian usia, jenis kelamin, pendidikan, } \\
\text { dan status perkawinan dapat berpengaruh terhadap } \\
\text { kecemasan. }\end{array}$ \\
\hline $\begin{array}{l}\text { Prevalence of anxiety towards COVID-19 and its } \\
\text { associated factors among healthcare workers in a } \\
\text { Hospital of Ethiopia } \\
\text { Penulis : Simegnew Kibret et.al (2020) }\end{array}$ & $\begin{array}{l}\text { PD. Prevalensi kecem } \\
\text { vak } 63 \% \text {. }\end{array}$ \\
\hline $\begin{array}{l}\text { COVID-19: anxiety among hospital staff and } \\
\text { associated factors } \\
\text { Penulis : Eliana Mattila, et.al (2020) }\end{array}$ & $\begin{array}{l}\text { Faktor resiko utama yang mempengaruhi kecemasan } \\
\text { yaitu usia, masalah kerja sama antar rekan kerja dan } \\
\text { beban kerja. }\end{array}$ \\
\hline $\begin{array}{l}\text { COVID-19: Causes of anxiety and wellbeing support } \\
\text { needs of healthcare professionals in the UK: A cross- } \\
\text { sectional survey } \\
\text { Penulis : Imrana Siddiqui, et.al (2020) }\end{array}$ & $\begin{array}{l}\text { Hasil penelitian ini faktor resiko kecemasan pada tenaga } \\
\text { kesehatan yaitu khawatir penularan covid19 dan } \\
\text { kurangnya APD. }\end{array}$ \\
\hline $\begin{array}{l}\text { Generalized Anxiety Disorder and Its Associated } \\
\text { Factors Among Health Care Workers Fighting } \\
\text { COVID-19 in Southern Ethiopia } \\
\text { Penulis : Abinet et. al (2020) }\end{array}$ & $\begin{array}{l}\text { Faktor yang berpengaruh terhadap kecemasan pada } \\
\text { tenaga kesehatan yaitu kontak dengan kasus yang } \\
\text { terkonfirmasi atau dicurigai, kekhawatiran terkait } \\
\text { COVID-19. }\end{array}$ \\
\hline $\begin{array}{l}\text { Risk factors for anxiety of otolaryngology healthcare } \\
\text { workers in Hubei province fghting coronavirus } \\
\text { disease } 2019 \text { (COVID-19) } \\
\text { Penulis : Xiuping Yang, et.al (2020) }\end{array}$ & $\begin{array}{l}\text { akan terpapar covid19 dan bekerja di bangsal } \\
\text { dapat berpengaruh terhadap kecemasan tenaga } \\
\text { tan }\end{array}$ \\
\hline $\begin{array}{l}\text { Factors Influencing Anxiety of Healthcare Workers } \\
\text { during the Outbreak of } 2019 \text { Novel Coronavirus } \\
\text { Disease (COVID-19): A Cross-Sectional } \\
\text { Penulis : Bazrafshan et al., (2020) }\end{array}$ & $\begin{array}{l}\text { Hasil penelitian faktor yang berpengaruh terhadap } \\
\text { kecemasan tenaga kesehatan adalah kontak dengan } \\
\text { pasien yang terinfeksi covid19. }\end{array}$ \\
\hline $\begin{array}{l}\text { Factors Influencing Anxiety of Health Care Workers } \\
\text { in the Radiology Department with High Exposure } \\
\text { Risk to COVID-19 } \\
\text { Penulis : Lei Huang et.al (2020) }\end{array}$ & $\begin{array}{l}\text { Tingkat kecemasan meningkat secara signifikan di HCP } \\
\text { selama pandemi COVID-19, dengan peningkatan } \\
\text { tertinggi pada dokter dan perawat. Alasan paling umum } \\
\text { yang diidentifikasi sebagai penyebab kecemasan terkait } \\
\text { dengan kekhawatiran tentang paparan covid19, dan } \\
\text { kurangnya APD. }\end{array}$ \\
\hline $\begin{array}{l}\text { Prevalence and predictors of anxiety among } \\
\text { healthcare workers in Saudi Arabia during the } \\
\text { COVID-19 pandemic } \\
\text { Penulis : Thamer H. et. al (2020) }\end{array}$ & $\begin{array}{l}\text { Bekerja di bangsal covid19 dan mempunyai penyakit } \\
\text { kronis mempengaruhi kecemasan tenaga kesehatan. }\end{array}$ \\
\hline
\end{tabular}

\section{PEMBAHASAN}

Dampak jangka panjang gangguan psikologis seperti kecemasan dapat mempengaruhi efisiensi kerja pada tenaga kesehatan. Kinerja tenaga kesehatan yang menangani covid 19 akan terhambat apabila kecemasan tidak dikelola dengan baik. Hasil penelitian dari 10 artikel tersebut menunjukan bahwa faktor-faktor yang mempengaruhi kecemasan pada tenaga kesehatan dimasa pandemi Covid19 yaitu jenis kelamin, status pernikahan, usia, ketersediaan APD, dan pengetahuan terhadap kecemasan tenaga kesehatan, pendidikan, tenaga medis yang pernah melakukan kontak langsung merawat pasien yang terinfeksi, mengidap penyakit kronis, beban kerja fisik dan psikis yang mengancam kesehatan, kekhawatiran 
tentang paparan SARS-CoV-2, kontak dengan pasien covid19, bekerja di bangsal isolasi infeksius, menderita penyakit kronis.

\section{Usia}

Faktor yang berpengaruh terhadap kecemasan tenaga kesehatan dimasa pandemi covid19 salah satunya yaitu usia. Usia memiliki pengaruh terhadap kecemasan. Responden dengan usia $\leq 30$ tahun lebih mudah mengalami kecemasan $(39,1 \%)$ dibandingkan dengan usia $>30$ tahun (26,1\%) kecemasan ringan [6]. Menurut penelitian [7] usia juga mempengaruhi kecemasan, hal tersebut dibuktikan oleh responden dengan usia $<30$ tahun lebih banyak mengalami kecemasan $(74,71 \%)$ dibandingkan dengan responden usia $>30$ tahun (25,29\%). Penelitian tersebut sejalan dengan teori Stuart yang mengatakan bahwa gangguan kecemasan lebih sering pada sesorang yang memiliki usia lebih muda karena berkaitan dengan koping seseorang dan tingkat perkembangan seseorang [8]. Responden usia 30-39 tahun atau sama dengan 40 tahun $(38,1 \%)$ dapat meningkatkan resiko kecemasan terhadap covid19 dibandingkan dengan reponden usia $<30$ tahun $(24,9 \%)$ [4]. Karena semakin berlanjutnya usia maka sistem kekebalannya menurun sehingga rentan terhadap penularan covid19. Namun penelitian [3] mengatakan bahwa usia tidak berpengaruh pada kecemasan hal tersebut dikarenakan setiap individu memiliki pengalaman yang berbeda dalam menangani kecemasan terhadap dirinya sendiri.

\section{Jenis Kelamin}

Jenis kelamin dapat mempengaruhi kecemasan, hal ini dibuktikan sebanyak $60 \%$ responden perempuan yang kontak dengan pasien mengalami kecemasan daripada laki-laki [7]. Hal tersebut sesuai teori Stuart yang mengatakan perempuan lebih mudah cemas karena perempuan lebih peka terhadap emosinya sehingga akan lebih peka terhadap rasa cemasnya [8].

\section{Pengetahuan}

Semakin tinggi pengetahuan sesorang maka Kemampuan analisis akan mempermudah individu dalam menguraikan masalah baru terutama kecemasan yang dirasakannya. Menurut penelitian [6] pengetahuan mempengaruhi kecemasan. Mayoritas tenaga kesehatan memiliki pengetahuan yang baik yaitu sebanyak 93 orang $(80,9 \%)$ terhadap pencegahan virus. Namun masih terdapat tenaga kesehatan dengan kecemasan ringan $(53,9 \%)$ hal tersebut disebabkan karena adanya tuntutan pekerjaan, meningkatnya jumlah pasien dan waktu kerja yang lama.

\section{Status Pernikahan}

Tenaga kesehatan yang memiliki keluarga mempunyai pengaruh kecemasan lebih tinggi dibandingkan dengan yang belum menikah. Hal tersebut dibuktikan oleh penelitian [4] sebanyak 106 orang (34,8\%) yang sudah menikah mengalami kecemasan. Penelitian [6] mengatakan sebanyak 67 orang $(58,2 \%)$ yang sudah berkeluarga mengalami kecemasan. Tenaga kesehatan yang sudah menikah memiliki pengaruh terhadap kecemasan karena pada saat merawat pasien positif Covid-19 mereka merasa khawatir dapat menularkan virus corona kepada keluarga [9].

\section{Ketersediaan APD}

Penelitian [4] mengatakan terdapat pengaruh ketersediaan alat pelindung diri (APD) terhadap kecemasan tenaga kesehatan pada pelayanan kesehatan. Sebanyak $144 \quad(28,6 \%)$ responden mengalami kecemasan karena kurangnya akses APD terhadap tenaga kesehatan. Sehingga penyediaan alat pelindung diri (APD) yang tepat sangat diperlukan. Kurangnya ketersediaan alat pelindung diri yang lengkap dan memadai menurut protokol WHO, tenaga kesehatan lebih 
mudah mengalami kecemasan dibandingkan dengan alat pelindung diri yang masih terbatas. Penelitian serupa oleh [10] mengatakan kurangnya APD di rumah sakit sangat meningkatkan tingkat kecemasan. Hal ini dibuktikan sebanyak 63 (17,3\%) responden dengan kecemasan ringan, $19(5,2 \%)$ responden mengalami kecemasan sedang dan $3(0,8 \%)$ reponden mengalami kecemasan berat. Sebanyak 48 $(13,2 \%)$ responden mengatakan APD yang tersedia kurang cukup [4]. Kurangnya APD meningkatkan kecemasan pada tenaga kesehatan dan peningkatan risiko pajanan terhadap covid19 sehingga berdampak negatif pada perasaan aman. Hal tersebut sejalan dengan hierarki kebutuhan Maslow bahwa keselamatan dan keamanan adalah salah satu kebutuhan dasar.

\section{Kontak Langsung}

Menurut penelitian [11] kontak langsung dengan pasien covid19 berpengaruh terhadap kecemasan tenaga kesehatan. Sebanyak $110(13,8 \%)$ tenaga kesehatan yang kontak dengan pasien covid19 mengalami kecemasan diantaranya 64 (58,2\%) kecemasan ringan, 34 (30,9\%) kecemasan sedang dan sebanyak 12 $(10,9 \%)$ responden mengalami kecemasan berat. Hal tersebut dikarenakan tenaga kesehatan yang kontak secara langsung memiliki kekhawatiran terkait tertularnya COVID-19, kemungkinan petugas kesehatan yang memiliki kekhawatiran terkait COVID19 lebih cenderung mengalami tingkat kecemasan yang lebih tinggi. Penelitian [12] juga mengatakan bahwa kontak langsung dengan pasien covid19 dapat berpengaruh terhadap kecemasan. hal tersebut dibuktikan $53 \quad(42,8 \%)$ responden mengalami kecemasan ringan, 37 (29,8\%) kecemasan sedang dan sebanyak 43 $(27,4 \%)$ responden mengalami kecemasan berat. Tenaga kesehatan yang merawat pasien secara langsung dengan Covid-19 memiliki tingkat kecemasan yang cenderung tinggi dibandingkan mereka yang melakukan kontak tidak langsung dengan pasien tersebut. Oleh karena itu, orang yang memiliki riwayat positif kontak dengan pasien Covid-19 rentan tingkat kecemasan yang lebih tinggi, yang dapat memiliki berbagai penyebab. Yang pertama karena risiko penularan penyakit pada orang-orang tersebut lebih tinggi akibat kontak dengan orang yang sakit, dan yang kedua adalah orang-orang ini memperhatikan kesehatan teman serta keluarga.

\section{Kekhawatiran Penularan}

Hasil literature review didapatkan ada pengaruh antara kekhawatiran penularan covid19 dengan kecemasan tenaga kesehatan dimasa pandemi covid19. Hal tersebut dibuktikan dari beberapa artikel penelitian yaitu penelitian [13] mengatakan Petugas kesehatan THT dalam mengkhawatirkan diri mereka dan anggota keluarga mereka. Demi keselamatan anggota keluarga, petugas kesehatan memilih untuk tinggal di hotel yang disediakan oleh pemberi kerja. Sedangkan menurut penelitian [14] mengatakan lebih dari sepertiga staf (763) takut mereka akan dipindahkan ke unit kerja baru selama wabah COVID-19. Selain itu, mereka khawatir mereka akan tertular virus corona saat bekerja dan bahwa mereka khawatir akan menginfeksi anggota keluarga.

\section{Penyakit Kronis}

Menurut penelitian [3] memiliki penyakit kronis dapat mempengaruhi kecemasan pada tenaga tenaga kesehatan. Sebanyak 547 tenaga kesehatan yang menderita penyakit kronis diketahui 147 orang mengalami kecemasan rendah, 185 orang mengalami kecemasan sedang dan sebanyak 215 orang mengalami kecemasan berat. Hal tersebut juga sejalan dengan penelitian [4] sebanyak 192 tenaga kesehatan yang memiliki penyakit kronis diketahui sebanyak 56 tenaga kesehatan $(18,4 \%)$ mengalami kecemasan. Hal ini dikarenakan penyakit

kronis mengakibatkan kekebalan tubuh penderita menjadi lemah sehingga sulit 
dalam melawan infeksi. Akibatnya, tubuh penderita dengan penyakit kronis mudah terjangkit penyakit, salah satunya yaitu covid19 [15].

\section{Beban Kerja}

Menurut penelitian [14] lebih dari setengah $(60 \%, \mathrm{n}=1.188)$ tenaga kesehatan di rumah sakit yang berpartisipasi merasa bahwa stres terkait pekerjaan mereka meningkat selama wabah COVID-19. Selain itu, 28\% (n = 537) responden merasa beban kerja meningkat selama wabah COVID-19 hingga mengancam kesehatan fisik dan psikologis mereka. Pekerja yang merasa stres terkait pekerjaan meningkat selama wabah COVID19 memiliki kecemasan yang lebih tinggi dari pada mereka yang tingkat stresnya tidak meningkat.

\section{Kerjasama antar Rekan Kerja}

Menurut penelitian (Elina Mattila et al., 2020) Mayoritas responden 90\% merasa bahwa kolaborasi antara rekan kerja berjalan mulus selama pandemi. Selain itu, $85 \%$ peserta memperkirakan bahwa semangat tim selama wabah berlangsung baik. Selain itu, 82\% staf merasa bahwa kerja sama antara berbagai profesi berjalan lancer XX. Teamwork adalah hal yang wajib dimiliki dalam setiap tim. Membangun teamwork yang solid dapat berdampak pada peningkatan produktivitas, kualitas kerja, serta loyalitas kerja. Jika kerjasama antar tenaga kesehatan kurang maksimal maka pelayanan kepada pasien akan terhambat dan mengalami banyak kendala. Banyak nya kendala atau masalah yang dihadapi dapat berdampak pada psikologis tenaga kesehatan salah satunya yaitu kecemasan [16].

\section{Bekerja di Bangsal Covid19}

Menurut penelitian [13] menemukan ada hubungan antara tempat bekerja dengan kecemasan. Hal ini menunjukkan bahwa pandemi COVID-19 telah mengenai semua tingkat layanan kesehatan dan tidak memandang tempat pekerjaan. Diketahui bahwa petugas kesehatan yang bekerja pada pelayanan kesehatan dan merawat pasien COVID-19 sebanyak 45 (52.94\%) beresiko dua kali lebih besar untuk mengalami kecemasan. Namun menurut penelitian [12] tidak ditemukan adanya kecemasan walaupun mayoritas responden bekerja di bangsal yang menangani pasien COVID-19. Hal tersebut dikarenakan penelitian dilakukan pada bulan November 2020 dimana kemungkinan tenaga kesehatan sudah mulai beradaptasi dengan kondisi pandemi sehingga mempengaruhi mekanisme coping yang menyebabkan tidak ditemukannya gejala cemas.

\section{SIMPULAN}

Kecemasan pada petugas kesehatan secara dinamis dapat mempengaruhi kinerja perorangan. Faktor-faktor yang mempengaruhi kecemasan pada tenaga kesehatan yaitu jenis kelamin, status pernikahan, usia, ketersediaan APD, dan pengetahuan terhadap kecemasan tenaga kesehatan, pendidikan, tenaga medis yang pernah melakukan kontak langsung merawat pasien yang terinfeksi, mengidap penyakit kronis, beban kerja fisik dan psikis yang mengancam kesehatan, kekhawatiran tentang paparan SARS-CoV-2, kontak dengan pasien covid19, bekerja di bangsal isolasi infeksius, tinggal bersama lansia, menderita penyakit kronis.

Faktor yang paling dominan berpengaruh terhadap kecemasan yaitu faktor usia karena semakin berlanjutnya usia maka sistem kekebalannya menurun sehingga rentan terhadap penularan covid19. Faktor yang kedua yaitu ketersediaan APD, karena Kurangnya APD meningkatkan kecemasan pada tenaga kesehatan dan peningkatan risiko pajanan terhadap covid19. Dan faktor yang ketiga yaitu kekhawatiran akan penularan, karena mereka khawatir akan tertular virus corona saat bekerja dan khawatir akan menginfeksi anggota keluarga. 


\section{UCAPAN TERIMA KASIH}

Terima kasih kepada pihak-pihak yang telah memberikan dukungan pada penulisan literature review serta berkenan menelaah, me-review dan memberikan sumbangan berupa masukan serta saran untuk pengembangan serta peningkatan kualitas ilmiah.

\section{REFERENSI}

[1] WHO. No Title. World Heal Organ 2021:1.

[2] Diinah D, Rahman S. Gambaran Tingkat Kecemasan Perawat Saat Pandemi Covid 19 Di Negara Berkembang Dan Negara Maju: a Literatur Review. Din Kesehat J Kebidanan Dan Keperawatan 2020;11:37-48. https://doi.org/10.33859/dksm.v11i1.555.

[3] Alenazi TH, Bindhim NF, Alenazi MH, Tamim H. Since January 2020 Elsevier has created a COVID-19 resource centre with free information in English and Mandarin on the novel coronavirus COVID- 19. The COVID-19 resource centre is hosted on Elsevier Connect, the company' s public news and information 2020.

[4] Kibret S, Teshome D, Fenta E, Hunie M, Tamire T. Prevalence of anxiety towards COVID-19 and its associated factors among healthcare workers in a Hospital of Ethiopia. PLoS One 2020;15:1-10.

https://doi.org/10.1371/journal.pone.024302 2.

[5] Hanggoro AY, Suwarni L, Selviana, Mawardi. Dampak psikologis pandemi COVID-19 pada petugas layanan kesehatan: studi. J Kesehat Masy Indones 2020;15:13-8.

[6] Fadli F, Safruddin S, Ahmad AS, Sumbara S, Baharuddin R. Faktor yang Mempengaruhi Kecemasan pada Tenaga Kesehatan Dalam Upaya Pencegahan Covid-19. J Pendidik Keperawatan Indones 2020;6:57-65. https://doi.org/10.17509/jpki.v6i1.24546.

[7] Liu CY, Yang YZ, Zhang XM, Xu X, Dou QL, Zhang WW. The prevalence and influencing factors for anxiety in medical workers fighting COVID-19 in China: A cross-sectional survey. MedRxiv 2020.

https://doi.org/10.1101/2020.03.05.2003200 3.
[8] \&NA; Principles and Practice of Psychiatric Nursing. $\quad$ vol. 1981. https://doi.org/10.1097/00000446198112000-00038.

[9] Shanafelt T, Ripp J, Trockel M. Understanding and Addressing Sources of Anxiety among Health Care Professionals during the COVID-19 Pandemic. JAMA - J Am Med Assoc 2020;323:2133-4. https://doi.org/10.1001/jama.2020.5893.

[10] Huang L, Wang Y, Liu J, Ye P, Chen X, Xu H, et al. Factors influencing anxiety of health care workers in the radiology department with high exposure risk to covid-19. Med Sci Monit 2020;26:1-9.

https://doi.org/10.12659/MSM.926008.

[11] Teshome A, Glagn M, Shegaze M, Tekabe B, Getie A, Assefa G, et al. Generalized anxiety disorder and its associated factors among health care workers fighting COVID-19 in southern Ethiopia. Psychol Res Behav Manag 2020;13:907-17. https://doi.org/10.2147/PRBM.S282822.

[12] Bazrafshan M. Factors Influencing Anxiety of Healthcare Workers during the Outbreak of 2019 Novel Coronavirus Disease (COVID-19): A Cross- Sectional Study 2021. https://doi.org/10.30476/jhsss.2020.88006.1 129.

[13] Yang X, Zhang Y, Li S, Chen X. Risk factors for anxiety of otolaryngology healthcare workers in Hubei province fighting coronavirus disease 2019 (COVID-19). Soc Psychiatry Psychiatr Epidemiol 2021;56:39-45. https://doi.org/10.1007/s00127-020-019283.

[14] A, PeltokoMattila, Elinski J, Neva MH, Kaunonen M, Helminen M, Parkkila AK. COVID-19: anxiety among hospital staff and associated factors. Ann Med 2021;53:237-46. https://doi.org/10.1080/07853890.2020.186 2905.

[15] Sudiono J. Sistem Kekebalan Tubuh. Penerbit Buku Kedokt EGC 2014:1-86.

[16] Rahma A, Mas'ud F. Pengaruh penerapan konsep team work dan budaya organisasi terhadap kinerja perawat (Studi pada rumah sakit umum daerah sunan kalijaga kabupaten Demak). Diponegoro J Manag 2016;5:1-11. 